Vol. 2, No. 2, Desember 2017, pISSN 2527-2853, eISSN 2549-2985

\title{
Adaptasi Elemen Desain Interior Pada Bangunan Kolonial (Studi Kasus: Restoran Honje Mangkubumi, Yogyakarta)
}

\author{
Paramita Waluyo \\ Magister Arsitektur Digital, Universitas Atma Jaya Yogyakarta, Yogyakarta \\ paramitawaluyo@gmail.com
}

\begin{abstract}
ABSTRAK
Restoran Honje Mangkubumi merupakan restoran yang terletak di jalan Margo Utomo nomor 125, Gowongan, Jetis, kota Yogyakarta. Area restoran Honje berada di lantai 2 yang tergabung dengan showroom kerajinan rajut tas tangan wanita Dowa pada lantai dasar. Bangunan Dowa Honje Mangkubumi merupakan bangunan kolonial yang mengalami perubahan fungsi. Peralihan fungsi bangunan dari toko kelontong menjadi showroom dan restoran membuat beberapa perubahan pada desain interior bangunan, khususnya restoran. Renovasi pada bangunan dilakukan dibeberapa titik, tanpa merubah bentuk aslinya. Konsep utama restoran yaitu, menciptakan suasana Tugu pada masa kolonial dibalut dengan gaya klasik modern. Tugu merupakan landmark kota Yogyakarta yang menjadi view utama restoran. Permasalahan penelitian ialah adaptasi desain interior yang dilakukan pada bangunan kolonial restoran Honje guna mendukung konsep restoran. Penelitian menggunakan pendekatan metode kualitatif deskriptif untuk menganalisa desain interior restoran terhadap adaptasi pada bangunan kolonial. Pengumpulan data dilakukan dengan obeservasi lapangan dan depth interview. Peneliti menggunakan referensi literature berupa buku, pustaka dan media internet sebagai pedoman menganalisis data. Waktu penelitian dilakukan bulan Maret hingga Juni 2017. Hasil penelitian restoran Honje dominan menggunaan warna, material, cahaya dengan warna alam, pada elemen pembentuk, pengisi dan pelengkap ruang. Dominasi perpaduan warna dari putih, coklat, dan gradasi biru pada pembentuk, pengisi dan pelengkap ruang mampu memberikan kesan modern sekaligus klasik pada bangunan. Bukaan pada dinding bangunan berupa pintu dan jendela jendela besar merupakan adaptasi yang memiliki pengaruh paling besar terhadap keberhasilan konsep restoran karena mampu menampilkan visual tugu secara keseluruhan dan membawa serta suasana disekitarnya kedalam bangunan.
\end{abstract}

Kata kunci: Restoran Honje; Adaptasi; Desain Interior

\section{ABSTRACT}

Honje Mangkubumi Restaurant located on Margo Utomo street number 125, Gowongan, Jetis, Yogyakarta. Honje's restaurant area is on the 2nd floor incorporated with Dowa woman handbag knitwear showroom on the ground floor. Dowa Honje Mangkubumi is a colonial building that undergoes change of function, from grocery store into showroom and restaurant made some changes to the interior design of the building. Renovation is done in some point, without changing the original shape. The main concept of the restaurant is creating the atmosphere of Tugu in colonial times wrapped with modern classical style. Tugu is a landmark of the city of Yogyakarta which became the main view of the restaurant. The research problem is interior design adaptation to support the concept of restaurant. Using a descriptive qualitative approach to analyze restaurant interior design on adaptation to colonial buildings. Data collection was conducted with obeservasi and in-depth interviews. Researchers use literature references books, libraries and internet media as data analysis. The study was conducted March to June 2017. The Honje restaurant's dominant use of colors, materials, light with natural colors, on the forming elements, filler and space complement. The dominance of the blend of colors from white, brown, and blue gradations on the shaper, cheap and complementary room capable of giving the impression of modern as well as classical on the 
building. Aperture on the walls of the building that is very influential on the appearance of the concept of buildings and buildings and buildings nearby.

Keywords: Honje Restaurant, Adaptation, Interior Design

\section{PENDAHULUAN}

Restoran Honje Mangkubumi merupakan restoran yang berdiri sejak tahun 2015, terletak di jalan Margo Utomo nomor 125, Gowongan, Jetis, kota Yogyakarta. Area restoran Honje berada di lantai 2 yang tergabung dengan handicraft accessories showroom berupa tas wanita, yaitu Dowa (doa; sansekerta) pada lantai dasar. Honje merupakan bahasa yang berasal dari suku sunda, yang memiliki arti bunga kecombrang. Kecombrang merupakan tumbuhan rumpun berakar rimpang (bercabang-cabang), buahnya berbentuk bulat seperti nanas. Memiliki nama ilmiah nicolaia hemisphaerica atau etlingera hemisphaerica (KBBI Daring, 2017). Pemilihan honje sebagai nama restoran diambil dari bahan utama untuk menu hidangan yang disajikan pada restoran.

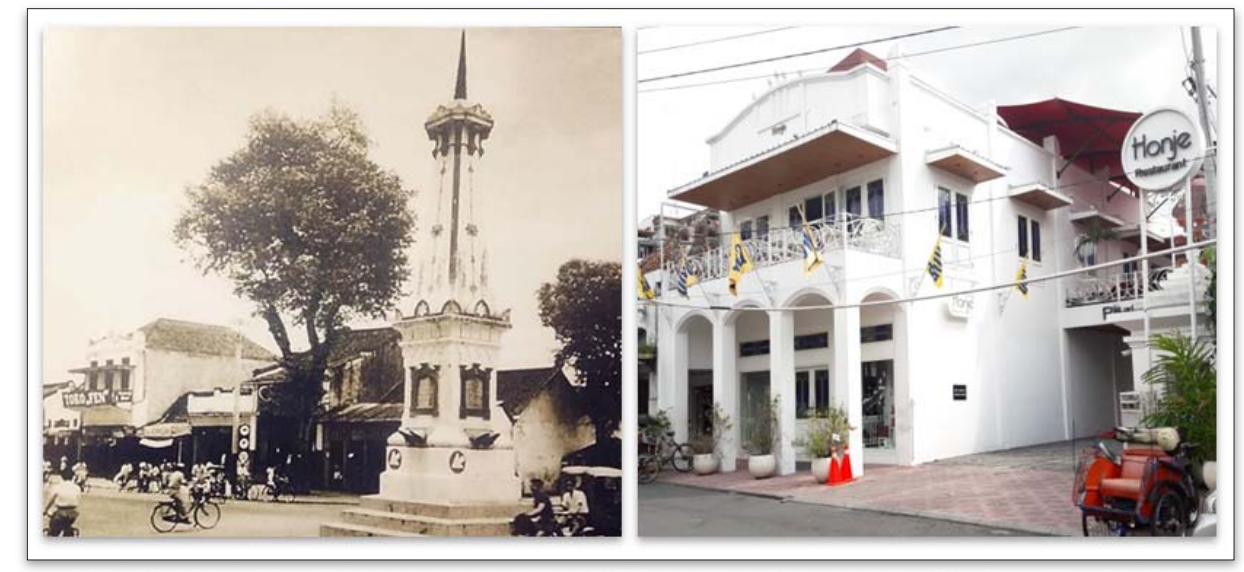

Gambar 1. Bangunan Kolonial sebagai Toko Kelontong Fen pada Tahun 1958 dan Restoran Honje Tahun 2017 Sumber: Sudibyo (2016) dan Dokumentasi Penulis (2017)

Bangunan Dowa Honje Mangkubumi merupakan bangunan kolonial yang beralih fungsi, yaitu toko kelontong Fen sebelum digunakan sebagai showroom dan restoran Dowa Honje Mangkubumi. Renovasi dilakukan pada beberapa titik, terutama pada bagian dengan kondisi rusak parah tanpa merubah bentuk aslinya, yaitu atap dan penutup lantai. Perubahan fasad yang terjadi yaitu pada sisi utara bangunan, berupa penambahan bukaan pada dinding, dan pembangunan lantai dak beserta pemasangan atap preumatik untuk area outdoor restoran. Area restoran Honje Mangkubumi terbagi menjadi 2, yaitu area indoor dan area outdoor. View utama restoran ialah Tugu yang menjadi landmark kota Yogyakarta. Peralihan fungsi bangunan membuat beberapa perubahan pada desain interior bangunan, khususnya pada restoran. Restoran Honje memiliki konsep utama menciptakan suasana Tugu pada masa kolonial dibalut dengan tampilan lebih modern.

Jam operasional restoran Honje Mangkubumi dimulai pukul 11.00 hingga pukul 23.00 wib, setiap hari dalam sepekan. Pada siang hari sebaran pengunjung terdapat pada area indoor, sedangkan pada sore dan malam hari penyebaran pengunjung lebih merata mengisi kedua area restoran yang menampilkan view utama restoran (Tugu) atau keadaan ruang luar, namun mayoritas pengunjung lebih utama memilih area outdoor pada sisi depan bangunan yang menampilkan view Tugu langsung secara keseluruhan, dan pada bagian indoor yang bearada pada bukaan jendela-jendela pada sisi utara bangunan menjadi pilihan setelahnya. 


\section{A. Permasalahan}

Berdasarkan pemaparan pada bagian pendahuluan penelitian, maka dapat ditarik rumusan masalah penelitian, yaitu "Bagaimana adaptasi desain interior bangunan kolonial pada restoran Honje guna mendukung konsep restoran?”

\section{B. Tinjauan Pustaka}

Menurut (D.K. Ching, 1996) elemen pembentuk ruang interior terbagi menjadi 2 yaitu elemen vertikal (dinding ) dan elemen horizontal (lantai, dan langit-langit). Elemen pelengkap pembentuk ruang yaitu utilitas bangunan, elemen pelengkap yang digunakan untuk menunjang tercapainya unsur kenyamanan, keselamatan, kesehatan, komunikasi dan mobilitas dalam bangunan, sedangkan elemen pengisi ruang merupakan furniture pada ruang.

\section{B.1. Pembentuk Elemen}

1. Garis

Tabel 1. Jenis-jenis Garis Lurus

\begin{tabular}{|c|l|l|}
\hline \multicolumn{2}{|c|}{ Predominant Lines } & \multicolumn{1}{c|}{ Evoked Responses } \\
\hline \multirow{5}{*}{ Straight } & Vertical & $\begin{array}{l}\text { - Ekspresi kekuatan dan pemaksaan. } \\
\text { - Atmosfer agung atau bermartabat. } \\
\text { - Efek ilusi pada ketinggian ruang. }\end{array}$ \\
\cline { 2 - 3 } & \multirow{5}{*}{ Horizontal } & $\begin{array}{l}\text { - Kesan luas atau lapang. } \\
\text { - Relaksasi. } \\
\text { - Efek tampak lebar. }\end{array}$ \\
\cline { 2 - 3 } & Diagonal & $\begin{array}{l}\text { - Kecenderungan menunjuk ke suatu ruang } \\
\text { dan membuat fokus penglihatan terus } \\
\text { bergerak. }\end{array}$ \\
\hline \multirow{5}{*}{ Curved } & $\begin{array}{l}\text { Circles and Full } \\
\text { Curves }\end{array}$ & $\begin{array}{l}\text { - Melemahtimulasikan keceriaan. } \\
\text { - Efek kegelisahan atau keresahan. }\end{array}$ \\
\cline { 2 - 3 } & $\begin{array}{l}\text { Voliptuous, full dan design. } \\
\text { complex }\end{array}$ & $\begin{array}{l}\text { - Garis dan bentuk berliku. } \\
\text { - Kesan indah dan kemewahan. }\end{array}$ \\
\cline { 2 - 3 } & $\begin{array}{l}\text { Softer, delicate } \\
\text { curved line and } \\
\text { shapes }\end{array}$ & $\begin{array}{l}\text { - Kurva lembut dengan kombinasi proporsi } \\
\text { - Kesan murni dan anggun. }\end{array}$ \\
& - Digunakan pada style klasik. \\
\hline
\end{tabular}

Sumber: (Lawson, 1987)

2. Warna

Warna dapat menciptakan susana dan efek emosional (Hartman, 1987).

Paduan warna yang digunakan pada suatu ruang menciptakan susana ruang lebih hidup dan tidak membosankan (Suptandar, 1991).

3. Material

Penggunaan material berpengaruh membentuk suasana ruang (Suptandar, 1991). 


\section{B.2. Elemen Pembentuk Ruang}

1. Dinding

Dinding merupakan elemen penting setiap bangunan karena berfungsi sebagai struktur pemikul lantai diatas di atas permukaan tanah . Dinding terbuat dari beberapa campuran material, sedangkan finishing dinding menjadi satu bagian yang tak terpisahkan dari material dinding tersebut (Oktavina, 2014).

Tabel 2. Bahan Pembentuk Suasana Ruang

\begin{tabular}{|l|c|}
\hline \multicolumn{1}{|c|}{ Kesan yang ditimbulkan } & Material Penutup Dinding \\
\hline Hangat, Alami, Indah, & Batu Alam \\
\hline Bersih, Luas, Rapi, & Cat \\
\hline Bersih, Luas, Rapi, Modern & Fiberglass \\
\hline Indah, Modern, & Gelas \\
\hline Sumber: (Suptandar, 1991)
\end{tabular}

2. Lantai

Karakter ruang dapat tercipta dari pola, warna dan tektur suatu penutup lantai. Lantai menyalurkan kualitas fisik terhadap keamanan saat berjalan. Lantai berwarna terang dapat meningkatkan kekuatan cahaya suatu ruang, sedangkan lantai gelap akan menyerap sebagian cahaya (Oktavina, 2014) .

Tabel 3. Bahan Pembentuk Suasana Ruang

\begin{tabular}{|l|l|}
\hline Kesan yang ditimbulkan & \multicolumn{1}{|c|}{ Material Penutup Lantai } \\
\hline \multirow{2}{*}{ Hangat, Alami, Indah, } & - Karpet \\
& - Parket \\
\hline \multirow{2}{*}{ Dingin, Sejuk } & - Serat Kayu \\
\hline & - Begel \\
& - Keramik \\
\hline Permanen, Kaku & - Marmer \\
& - Teraso \\
\hline Indah, Sejuk, Luas & - Granit \\
\hline Atraktif, Dinamis & - Keramik Tile \\
\hline Sumber: (Suptandar, 1991) & - Tegel Motif \\
\hline
\end{tabular}

3. Langit-langit

Langit-langit dibentuk bagian bawah struktur lantai dan atap. Pola langit-langit menarik perhatian dan tampak lebih rendah dari sebenarnya sebagai akibat bobot visualnya (Oktavina, 2014). 
Tabel 4. Bahan Pembentuk Suasana Ruang

\begin{tabular}{|l|l|}
\hline \multicolumn{1}{|c|}{ Kesan yang ditimbulkan } & \multicolumn{1}{|c|}{$\begin{array}{c}\text { Material Penutup Langit- } \\
\text { langit }\end{array}$} \\
\hline Rapi, Bersih, Sederhana, & $\begin{array}{l}\text { - Kayu } \\
-\end{array}$ \\
\hline Alami, Hangat, & - Triplek \\
\hline Dingin, Kaku, Modern & - Logam (Siring) \\
\hline
\end{tabular}

Sumber: (Suptandar, 1991)

\section{B.3. Elemen Pengisi Ruang}

Elemen pengisi ruang menjadi perantara antara arsitektur dan penghuninya, dengan transisi bentuk dan skala antara ruang dan masing-masing individu. Kualitas perabot pengisi ruang dapat mempengaruhi kenyamanan fisik, contohnya faktor penataan, penggunaan, jenis dan lama kegiatan, kualitas pencahayaan, dan kondisi pikiran penghuni (Ching, 1996).

\section{B.4. Elemen Pelengkap Ruang}

Utilitas bangunan merupakan pelengkap untuk menunjang tercapainya kenyamanan, keselamatan, kesehatan, komunikasi dan mobilitas dalam bangunan. Utilitas meliputi instalasi tata udara, listrik, penangkal petir, plumbing, komunikasi. Penelitian hanya membahas faktor yang berkaitan dengan penghawaan dan pencahayaan bangunan.

\section{METODE}

Objek penelitian yaitu Restoran Honje mangkubumi, yang terletak di jalan mangkubumi nomor 125, Gowongan Jetis, kota Yogyakarta. Waktu penelitian dilakukan terhitung bulan Maret hingga Juni 2017. Penelitian menggunakan pendekatan metode kualitatif deskriptif untuk menganalisa adaptasi desain interior restoran pada bangunan kolonial. Pengumpulan data sekunder dilakukan dengan obeservasi lapangan dan depth interview. Observasi dilakukan sesuai pembagian rentang waktu selama restoran beroprasi, yaitu siang, sore dan peak hour kunjungan dari pelanggan Restoran Honje Mangkubumi. Peneliti menggunakan referensi literatur berupa buku, jurnal, pustaka dan media internet sebagai pedoman menganalisis data.

\section{HASIL PENELITIAN DAN PEMBAHASAN}

\section{A.1. Elemen Pembentuk Ruang}

\section{Dinding}

Data lapangan dan teori

Bahan : Cat pada penutup dinding memberikan suasana bersih, luas dan rapi (Suptandar, 1991). Kaca menciptakan suasana indah dan modern.

Warna : Putih memiliki memiliki karakter netral, bersifat polos, suci, bersih, dingin, dan ringan, serta memberikan efek relaksasi (Widyartanti, 2010).

Bentuk : Geometris, segi empat sisi memiliki sifat stabil, memiliki batas dan monoton (Teori Nirmana Dwimatra).

Pembahasan

Material pelapis dinding yang digunakan pada interior restoran Honje ialah cat dengan spesifikasi warna putih. Dinding berwarna putih memberikan kesan putih, bersih, modern dan luas. Hal tersebut sesuai dengan konsep restoran yang ingin menampilkan tema 
modern klasik pada bangunan. Pada beberapa titik dinding interior bangunan, dinding digunakan sebagai latar belakang identitas restoran, berupa lukisan honje. Sedangkan pada sisi dinding sebelah kiri terdapat titik point berupa hiasan dinding dari kumpulan foto yang dirangkai menjadi satu. Hiasan dinding menggunakan material kayu dengan warna-warna netral dan alami, yaitu coklat.

2. Lantai

Data lapangan dan teori

Bahan : Tegel, mempunyai karakteristik alamiah dingin, memberikan kesan sejuk (Tauhidia, 2016).

Motif : Memiliki sifat aktraktif dan dinamis (Akmal, 2007), namun memiliki sifat irama repetisi yang adalah kuat, resmi dan cenderung monoton (Teori Nirmana Dwimatra).

Warna : Coklat memiliki karakter dekat dengan tanah dan kayu, dapat menghangatkan suasana dan rasa nyaman (Widyartanti, 2010). Putih memiliki memiliki karakter netral, bersifat polos, suci, bersih, dan dingin (Widyartanti, 2010).

Garis : Diagonal memiliki sifat menarik perhatian penglihatan untuk terus terfokus mengamati suatu desain (Lawson, 1987). Bergerak dan giat (Teori Nirmana Dwimatra).

Bentuk: Geometris, segi empat sisi memiliki sifat stabil, memiliki batas dan monoton (Teori Nirmana Dwimatra).

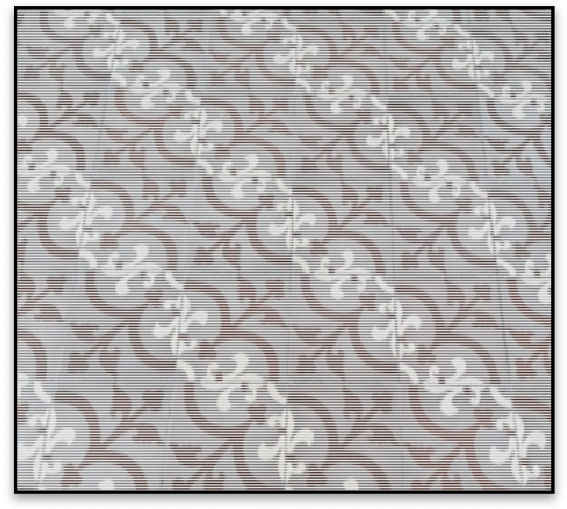

Gambar 2. Penutup Lantai Restoran Honje Sumber: Dokumentasi Penulis (2017)

Pembahasan

Bangunan Dowa Honje Mangkubumi menggunakan tegel sebagai material penutup lantai pada seluruh ruang. Penggunaan tegel pada setiap ruang memiliki warna dan motif yang berbeda. Penekaan perbedaan warna meunjunkkan batas fungsi pada tiap-tiap ruang. Tegel memiliki sifat alamiah dingin dan berkesan sejuk pada bidang pengaplikasian. Tegel pada pada lantai area indoor restoran memiliki motif dengan pola lengkung; bentuk alam. Motif pada tegel memiliki irama yang berkesinambungan, dan memiliki perpaduan warna gradasi coklat dan putih, yang memberikan kesan dingin dan nyaman. 
3. Langit-langit

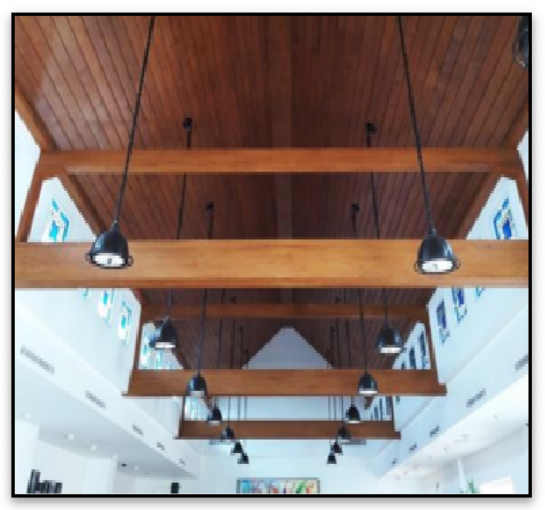

Gambar 3. Langit-langit Restoran Sumber: Dokumentasi Penulis (2017)

Data lapangan dan teori:

Bahan : Kayu, memberikan kesan alami dan hangat pada bidang atau ruang.

Warna : Coklat memiliki karakter dekat dengan tanah dan kayu, dapat menghangatkan suasana dan memberikan rasa nyaman. Putih memiliki karakter netral, bersifat polos, suci, bersih, dingin, dan ringan, serta memberikan efek relaksasi. Perpaduan warna coklat dan putih menciptakan kesan suasana modern (Widyartanti, 2010).

Garis : Horizontal pada bidang plafond memberikan kesan relaksasi karena efek luas yang ditimbulkan. Penerapan garis diagonal pada langit-langit memberikan batasan ruang pada area yang dinaungi (Lawson, 1987).

Bentuk : Geometri berbentuk segitiga. Memberikan kesan aktif, stabil karna ditopang Pembahasan oleh dua sudut pembentuk struktur utama segitiga.

Kayu merupakan material utama pembentuk langit-langit restoran. Perpaduan penggunaan garis diagonal dan horizontal, pada bentuk langit-langit serta hadirnya palangpalang kayu sebagai elemen pembentuk langit-langit ruang memberikan kesan pembatas area, mempertegas bentuk segitiga pada langit-langit. Bentuk segitiga memberikan kesan aktif, stabil karna ditopang oleh dua sudut pembentuk struktur utama segitiga. Drop ceilling pada restoran menggunakan material gypsum dan putih sebagai warna pelapis materialnya. Penggunaan material dan warna dominan pada langit-langit, yaitu kayu dan coklat memberikan kesan dominan hangat dan alami pada ruang, menciptakan kesan intim pada langit-langit yang menjulang keatas berbentuk geometri.

\section{A.2. Elemen Pengisi Ruang}

Aplikasi penerapan elemen pengisi ruang restoran menggunakan penggabungan bentuk dinamis (lengkung, lingkaran) dan statis (garis, kotak). Desain perabot kursi, sofa dan meja dibuat secara khusus mengikuti luasan ruangan, dan elemen pelengkap ruang, yaitu bukaan jendela-jendela besar pada dinding bagian utara. 


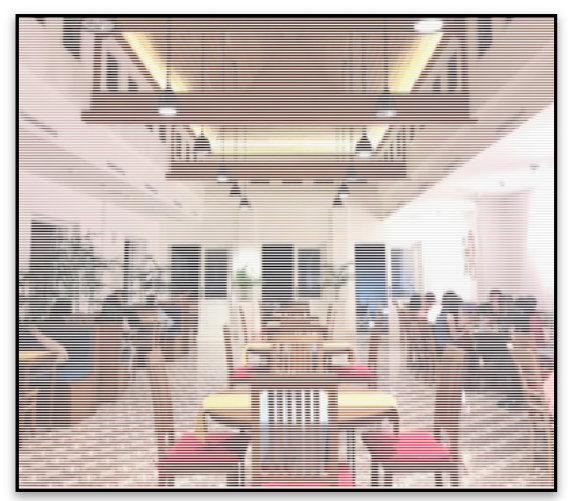

Gambar 4. Perabot Pengisi Ruang Restoran Sumber: Dokumentasi Penulis (2017)

Penerapan warna pada perabot menekankan pada warna-warna klasik alami yang menimbulkan suasana hangat sesuai dengan konsep restoran. Warna coklat merupakan warna alami, yang memiliki sifat hangat dan friendly. Warna sub-dominan menggunakan warna primer, yaitu merah memberikan kesan keberanian, semangat, dan kekuatan. Warna biru secara psikologis menciptakan ketenangan, kepercahayaan dan kesan mendalam (Satwiko, 2017). Area langit-langit terdapat lampu gantung sebagai pengisi ruang. Lampu-lampu gantung dipasang berjajar dengan jarak tertentu. Penggunaan lampu gantung sebagai pengisi area langit-langit menciptakan perubahan persepsi visual terhadap skala bentuk langit-langit yang menjulang tinggi menjadi lebih rendah dan bersahabat. Penggunaan warna hitam untuk lampulampu gantung memiliki sifat kuat dan memberikan kesan memperkuat, dan mempertajam elemen disekitarnya.

\section{A.3. Elemen Pelengkap Ruang}

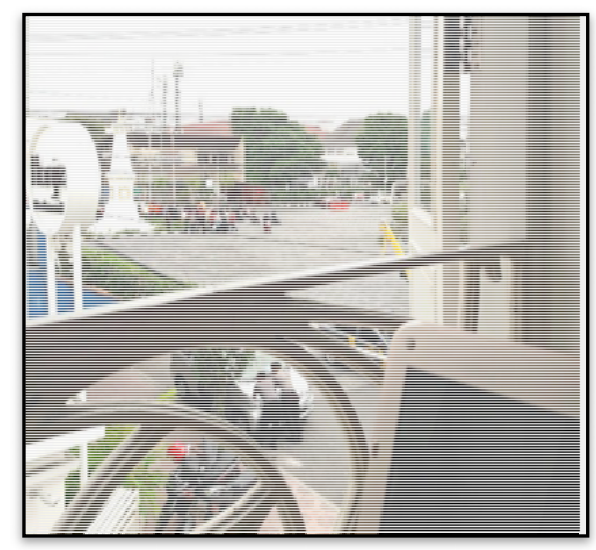

Gambar 5. View dari Jendela Area Indoor Restoran Sumber: Dokumentasi Penulis (2017)

Restoran Honje Mangkubumi menggunakan penghawaan alami dengan membuat bukaanbukaan pada dinding ruang untuk mengaliri udara kedalam area indoor restoran. Bukaan pada dinding merupakan salah satu perubahan pada bangunan. Restoran menggunakan pintu dan jendela-jendela besar dengan perpaduan material kayu dan kaca patri. 
Selain berfungsi sebagai jalur aliran penghawaan pada bangunan, jendela-jendela besar pada sisi utara bangunan sengaja dirancang untuk memberikan view dan menciptakan suasana Tugu Yogyakarta. Terbukanya pintu dan jendela-jendela besar membuat penghawaan indoor restoran bergantung pada kondisi cuaca sehari-hari. Sedangkan untuk menyelesaikan masalah penghawaan pada siang hari restoran menggunakan stand kipas angin di dua titik, yaitu 1 titik di area indoor bangunan dan 1 titik di area outdoor.

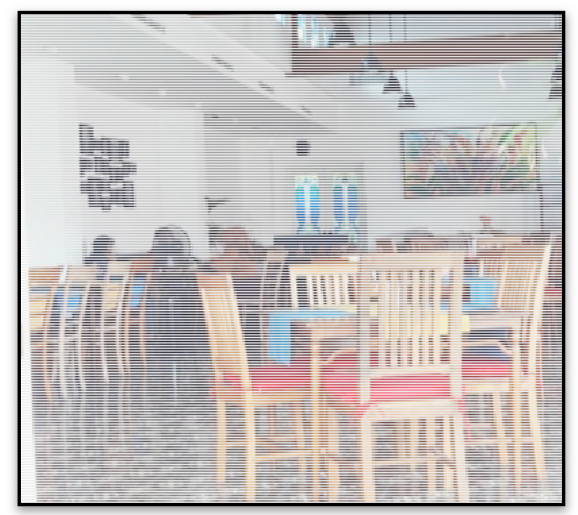

Gambar 6. Titik Pengunjung pada Siang hari Sumber: Dokumentasi Penulis (2017)

Bukaan-bukaan tersebut berdampak pada penyebaran pengunjung yang lebih dominan mengisi titik-titik pada area di samping jendela daripada titik-titik lain dalam area indoor restoran terutama pada waktu sore hingga malam hari berbanding terbalik pada siang hari. Tersedianya ducting ac pada indoor restoran menandakan perencanaan penghawaan memiliki 2 jenis yaitu alami dan buatan. pengunjung memiliki kecenderungan memilih area yang berdekatan dengan stand kipas angin.

Sebagai langkah untuk mengoptimalkan view restoran seluruh jendela dan pintu pada restoran dibuka pada waktu siang dan malam hari, yang berpengaruh pada penghawaan didalam bangunan, khususnya pada siang hari. Pada siang hari pemanfaatan jendela dan pintu sebagai sumber pencahayaan, dan penghawaan pada bangunan turut membawa udara panas luar masuk kedalam bangunan.

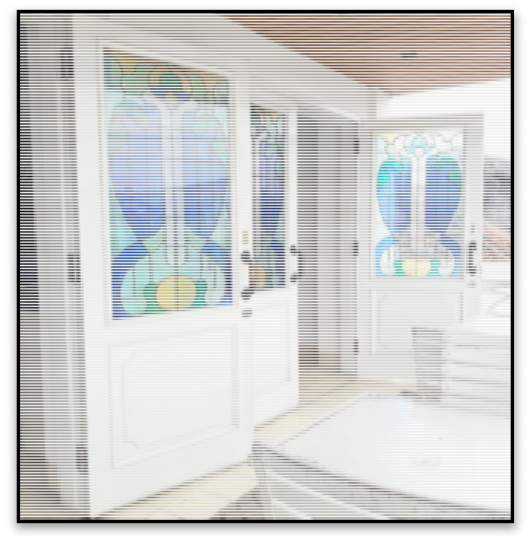

Gambar 7. Bukaan pada Dinding Restoran berupa Pintu dan Jendela Sumber: Dokumentasi Penulis (2017) 
Warna pada elemen pelengkap penghawaan ruang, yaitu jendela dan pintu dominan putih dan gradasi biru pada kaca patri. Putih merupakan warna klasik yang memiliki karakter netral, bersifat polos, suci, bersih, dingin, dan ringan, serta memberikan efek relaksasi (Widyartanti, 2010). Warna biru merupakan penekanan terhadap kesan modern. Secara psikologis menciptakan ketenangan, kepercahayaan dan kesan mendalam (Satwiko, 2017). Sinar matahari merupakan sumber pencahayaan restoran pada siang hari. Sinar matahari masuk melalui dari jendela dan boven kaca yang tersebar pada dinding bagian bawah langit langit. Boven terpasang berjajar dengan jarak tertentu mengelilingi bentuk ruang, dan menggunakan material kaca patri dengan warna senada dengan jendela dan pintu. Sedangkan pada malam hari pencahayan buatan pada area indoor restoran menggunakan lampu dengan pencahayaan langsung dan tidak langsung.

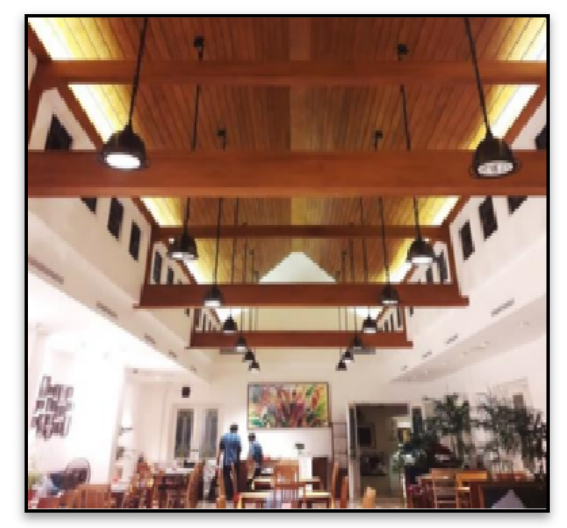

Gambar 8. Pencahayaan Indoor Restoran Sumber: Dokumentasi Penulis (2017)

Pencahayaan pada langit-langit ruang menggunakan pencahayaan tidak langsung, yaitu memantulkan sumber cahaya pada objek yang dituju. Mengelilingi sisi tepi garis horizontal langit-langit dengan penggunaan cahaya berwarna kuning. Lampu pada langit-langit area indoor restoran berfungsi sebagai pembentuk ambience ruangan, memberikan kesan elegant, hangat, dan nyaman. Cahaya utama ruang berasal dari lampu gantung yang dipasang berjajar menjulur kebawah pada langit-langit ruang. Penyebaran arah cahaya pada lampu terbatas sehingga titik tik ampu dipasang berjajar mengisi area langit langit. Lampu gantung yang dipasang berjajar memberikan kesan panas pada ruang dibawahnya, sehingga pada malam hari tidak semua lampu di operasikan. Cahaya putih pada lampu memberikan kesan luas dan bersih pada ruang.

\section{KESIMPULAN}

Berdasarkan hasil analisa dan pembahasan diatas maka dapat ditarik kesimpulan, yaitu:

1. Restoran Honje dominan menggunaan warna, material, cahaya dengan warna alam, baik pada elemen pembentuk, pengisi dan pelengkap ruang.

2. Dominasi perpaduan warna dari putih, coklat, dan gradasi biru pada pembentuk, pengisi dan pelengkap ruang mampu memberikan kesan modern sekaligus klasik pada bangunan.

3. Bukaan pada dinding bangunan berupa pintu dan jendela jendela besar merupakan adaptasi yang memiliki pengaruh paling besar terhadap keberhasilan konsep restoran, karena mampu menampilkan visual tugu yang menjadi landmark kota Yogyakarta secara keseluruhan dann membawa serta suasana disekitarnya kedalam bangunan. 


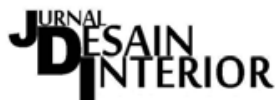

Vol. 2, No. 2, Desember 2017, pISSN 2527-2853, eISSN 2549-2985

\section{DAFTAR PUSTAKA}

Akmal, I. (2007). Rumah Ide: Lantai. Indonesia: Gramedia Pustaka Utama.

Blackburn, S. (2008). Oxford Dictionary of Philosophy. United Kingdom: Oxford University Press.

Ching, F. D. (1996). Ilustrasi Desain Interior. Jakarta: Erlangga.

Conway, H., \& Roenisch, R. (2005). Understanding Architecture. New York: Routledge.

Dillistone, F. W. (2002). The Power of Symbols. Yogyakarta: Kanisius.

Geertz, C. (2013). Agama Jawa : Abangan, Santri, Priyayi dalam kebudayaan Jawa. Depok: Komunitas Bambu.

Grosslight, J. (1984). Effective Use of Daylight and Electric Lighting in Residental and Commercial Spaces. New Jersey: Prentice Hall Inc.

Hartman, T. (1987). The Color Code. California.

Haryanto, S. (2010). Teori Strukturalisme : dalam Anatomi dan Perkembangan Ilmu Sosial. Yogyakarta: Bagong Suyanto dan M. Khusna Amal (ed) Aditya Media.

Hashemnezhad, H., Heidari, a. A., \& Hoseini, P. M. (Vol. 3, No. 1. 2013). Sense of Place and Place Attachment. International Journal of Architecture and urban Development, 312.

Hernandez, B., Hidalgo, M. C., \& M. Esther Salazar-Laplace, S. H. (2007). Place Attachment and Place Identity in Natives \& Non Natives. Journal of Environmental Psychology, 310-319.

Hidajat, R. (2006). Relasional Simbolis Desa, Sungai dan Pundhen dengan pertunjukan wayang topeng malang di dusun kedungmonggo, karangpandan. Kejawen, Jurnal Kebudayaan Jawa, 14-37.

Hidalgo, M. C., \& Hernandez, B. (2001). Place Attachment : conceptual and Empirical Question. Journal of Environmental Psychology, 273-281.

Istiawan, S., \& Kencana, I. P. (2006). Ruang Artistik Dengan Pencahayaan. Jakarta: Kepustakaan Populer Gramedia.

Joel, A. (2011, 11 1). Sustainable Design: Definisi, Prinsip dan Standard. Diambil kembali dari http://vitate-a-joel.blogspot.co.id/2011/11/sustainable-design-definisi-prinsipdan.html

KBBI Daring. (2017). Dipetik Juni 13, 2017, dari Kamus Besar Bahasa Indonesia (KBBI): http://kbbi.web.id/kecombrang

KWI, K. T. (2012). Kompendium Konsili Vatikan II. Yogyakarta: Kanisius.

Laksana, A. B. (2011). Journeying to God in Communion With The Other: A Comparative Theological Study of The Muslim and Catholic Pilgrimage Traditions in South Central Java and Their Contributions To The Catholic Theology of Communio Sanctorum. United States: UMI Dissertation Publishing.

Lawson, F. (1987). Restaurant, Club and Bars. London: Van Nostrand Reinhold Company.

Lim, I. (2013, 2 23). Eco Green / Green Design . Diambil kembali dari Green Design / Eco design: http://inggridlim12.blogspot.co.id/2013/02/eco-green-green-design.html

M, D. E., \& Victor, W. O. (2002). Architectural Lighting. New York: McGraw-Hill.

Magee, B. (2008). The Story of Philosophy. Yogyakarta: Kanisius.

Magnis-Suseno, F. (2003). Etika Jawa. Jakarta: PT. Gramedia Pustaka Utama.

Mangunwijaya, Y. B. (1988). Wastu Citra. Yogyakarta: PT. Gramedia.

Mazumdar, S., \& Mazumdar, S. (2004). Religion and Palce Attachment : A Study of Sacred Places. Journal of Environmental Psychology, 385-397. 
Oktavina, G. (2014). Studi Pengaruh Tata Ruang Terhadap Tingkat Kepuasan Konsumen di Malioboro Mall, Galeria Mall, dan Ambarukmo Plaza Yogyakarta. Yogyakarta: Program Studi Magister Arsitektur.

Pennick, N. (1980). Sacred Geometry. Northamptonshire: Weatherby Woolnough.

R, G. H., \& J, D. K. (1972). The LIghting of Building. London: Faber \& Faber Limited.

Rustiadi, E., Saefulhakim, S., \& Panuju, D. R. (2009). PERENCANAAN DAN PENGEMBANGAN WILAYAH. Jakarta: YAYASAN PUSTAKA OBOR INDONESIA.

S Condronegoro, M. (2012, JUni 03). Makna Filosofis Motif Kain Batik. Dipetik 06 14, 2017, dari Javanese Culture : https://diasraka.wordpress.com/2012/06/03/filosofis/

Satwiko, P. (2004). Fisika Bangunan. Yogyakarta: Penerbit Andi Yogyakarta.

Satwiko, P. (2017, 03). Arti Warna pada Pencahayaan.

Sheldrake, P. (2001). Spaces for the Sacred : Place, Memory, and Identity. Baltimore, Maryland: John Hopkins University Press.

Simmins, G. (2008). Sacred Spaces and Sacred Places. VDM Verlag.

Srisadono, Y. D. (2012). Konsep Sacred Space dalam Arsitektur Gereja Katolik. Melintas, 182-206.

Suptandar, J. P. (1991). Desain Interior: Pengantar Merencana Interior untuk Mahasiswa Desain dan Arsitektur. Jakarta: Djambatan.

Suryanugraha, C. H. (2006). Rupa dan Citra: Aneka Simbol dalam Misa. Bandung: SangKris. Sutrisno, M., \& Putranto, H. (2005). Teori - Teori Kebudayaan. Yogyakarta: Kanisius.

Tauhidia, N. (2016, 07 28). Interior 101: Jenis Material Lantai. Dipetik 06 14, 2017, dari Binus University: http://scdc.binus.ac.id/himdi/2016/07/28/interior-101-jenis-materiallantai/

Tedjoworo, H. (2012). Re-interpreting the Catholic's Images of the Church in Java Part II. Melintas, 139-160.

Teori Nirmana Dwimatra. (t.thn.).

Utomo, R. G. (2011). Gereja Hati Kudus Yesus di Ganjuran. Yogyakarta: Unggul Jaya.

Waxman, L. (2006). The Coffee Shop : Social and Physical Factors Influencing Place Attachment. Journal of Interior Design, 35-53.

Widagdo. (2011). Desain \& Kebudayaan. Bandung: Penerbit ITB.

Widyartanti, J. E. (2010). Color of Harmonies. Jakarta: PT. Gramedia.

Williams, D. R., Patterson, M. E., \& Rogenbuck, J. W. (1992). Beyond The Commodity Metaphor : Examining emotional and Symbolik Attachment to Place. Leisure Science, 29-46. 